Article

\title{
Evaluation of Gas Emissions, Energy Consumption and Production Costs of Warm Mix Asphalt (WMA) Involving Natural Zeolite and Reclaimed Asphalt Pavement (RAP)
}

\author{
Alejandra T. Calabi-Floody *(D), Gonzalo A. Valdés-Vidal, Elsa Sanchez-Alonso ${ }^{(D)}$ and \\ Luis A. Mardones-Parra \\ Department of Civil Engineering, Universidad de La Frontera, Temuco 1145, Chile; \\ gonzalo.valdes@ufrontera.cl (G.A.V.-V.); elsa.sanchez@ufrontera.cl (E.S.-A.); \\ luis.mardones.p@ufrontera.cl (L.A.M.-P.) \\ * Correspondence: alejandra.calabi@ufrontera.cl; Tel.: +56-(45)-232-56-80
}

Received: 3 June 2020; Accepted: 22 July 2020; Published: 10 August 2020

\begin{abstract}
Asphalt mixture is the most widely used material in road construction, and the industry is developing more sustainable technologies. Warm mix asphalt (WMA) is a promising alternative as it saves energy, reduces fuel consumption and generates fewer gas and fume emissions, while maintaining a similar performance to hot mix asphalt (HMA). This paper presents an evaluation of the gas emissions at laboratory scale, as well as the energy consumption and production costs, of five types of WMA with the addition of natural zeolite. The control mixture was a HMA manufactured at $155^{\circ} \mathrm{C}$. The mixtures evaluated were two WMA manufactured at $135{ }^{\circ} \mathrm{C}$ with $0.3 \%$ and $0.6 \%$ natural zeolite, and three WMA with partial replacement of raw materials by $10 \%, 20 \%$ and $30 \%$ of reclaimed asphalt pavement (RAP); these mixtures, called WMA-RAP, were manufactured at $125^{\circ} \mathrm{C}, 135^{\circ} \mathrm{C}$ and $145{ }^{\circ} \mathrm{C}$, respectively. The results indicated that all the mixtures evaluated reduced $\mathrm{CO}$ and $\mathrm{CO}_{2}$ emissions by $2-6 \%$ and $17-37 \%$, respectively. The energy consumption presented a $13 \%$ decrease. In the current situation, the production costs for WMA with 0.3 and $0.6 \%$ natural zeolite are slightly higher than the control mixture, because the saving achieved in fuel consumption is lower than the current cost of the additive. On the other hand, WMA manufactured with the addition of natural zeolite and RAP could produce cost savings of up to $25 \%$, depending on the amounts of RAP and natural zeolite used.
\end{abstract}

Keywords: warm mix asphalt; natural zeolite; gas emissions; energy consumption; production costs

\section{Introduction}

Worldwide, environmental awareness has forced governments and leaders to take action to protect the planet from global warming and climate chaos. This trend was formalized in the Kyoto protocol (1997), where the main goal was to reduce greenhouse gas emissions [1], and reaffirmed in the Paris Agreement. In this context, the asphalt industry is currently developing more sustainable technologies.

Hot mix asphalt (HMA) is the most widely used construction material for paving roads. Nearly $90 \%$ of paved roads in the world are made of asphalt mixtures [2]. In Europe, more than $90 \%$ of paved roads are made of asphalt materials. Similar levels are found in the United States, Canada and Mexico, where the use of asphalt for paved roads exceeds $92 \%, 90 \%$ and $96 \%$, respectively [3]. Asphalt mixtures use asphalt binder, aggregates (sand and crushed rock) and mineral filler. This mixture is produced at high temperatures, between $150^{\circ} \mathrm{C}$ and $190^{\circ} \mathrm{C}$, depending of the type of asphalt binder used. In the field, the mixture is spread and compacted on the road at high temperatures $\left(120-140{ }^{\circ} \mathrm{C}\right)$. During these 
processes (production, storage and handling at high temperatures), a complex mixture of gases is released into the atmosphere [4] and a large amount of energy is consumed [4,5]. At the same time, large volumes of raw materials are required due to the high demand for HMA [3]. As mentioned above, technologies are needed to produce sustainable pavements, focusing on reducing emissions, saving energy and conserving natural resources [6], while keeping costs as low as possible. Some researchers have identified and quantified asphalt mixture emissions, both in the plant and in the laboratory $[7,8]$, resulting in different techniques for reducing emissions. Quian et al. [9] proposed adding different fume suppressor agents, observing that by adding 3\% of SBS, PE, melamine, nano-calcium carbonate and activated carbon in separate tests, asphalt fumes were reduced by $19.2 \%, 6.5 \%, 45.1,4.8 \%$ and $41.6 \%$, respectively. Autelitano et al. [4] concluded that a $30{ }^{\circ} \mathrm{C}$ reduction in the manufacturing temperature of asphalt mixture, achieved by the addition of wax, cut emissions by half. Croteau and Tessier [10] showed that a reduction of $20^{\circ} \mathrm{C}$ in the manufacturing temperature decreased greenhouse gas emissions by between $20 \%$ and $35 \%$, with a fuel saving of $21 /$ ton of mixture. One of the main greenhouse gases is $\mathrm{CO}_{2}$, which in asphalt paving is generated by two principal mechanisms: energy consumption during mixing and compaction processes; and binder oxidation at the high temperatures required for mixing [11]. These processes involve $\mathrm{CO}_{2}$ generation through molecular reaction by hydrocarbon oxidation [12]. Some authors have indicated that naphthenic aromatic and polar aromatic compounds are the principal components responsible for $\mathrm{CO}_{2}$ emissions $[13,14]$. This agrees with the study by Brandt and De Groot [15], who concluded that in the temperature range between $140^{\circ} \mathrm{C}$ and $190^{\circ} \mathrm{C}$, the fume-emission rate increased by a factor of 2 for each $12{ }^{\circ} \mathrm{C}$ increase in temperature. Therefore, reducing the manufacturing temperature of asphalt mixtures would appear to be the most effective way of reducing $\mathrm{CO}_{2}$ emissions during asphalt mixture production and pavement construction [12].

In the report presented by West et al., an average fuel saving of $22.1 \%$ was obtained by a temperature reduction of $9{ }^{\circ} \mathrm{C}$ in the asphalt mixture [16]; thus, reducing manufacturing temperatures helps to reduce energy consumption [17]. Many of the sustainable technologies reported relate to methods for producing warm mix asphalt (WMA) because these technologies help to decrease both energy consumption and emissions, and in some cases production costs (the reduction in fuel consumption may help compensate for the cost of WMA additive or equipment) $[10,16]$. WMA technologies allow the reduction in manufacturing and compaction temperatures without affecting mixture performance [18]. Mohd et al. indicated that energy savings between $23 \%$ and $29 \%$ are possible through the use of WMA rather than HMA [19].

WMA technologies are classified in three major categories: asphalt foaming technologies, organic additives and chemical additives [18]. The benefits of these technologies include reducing emissions, saving energy, reducing fuel consumption, extending the paving season, reducing workers' exposure to gas and temperature, and improving field compaction, as well as the potential for including a higher proportion of reclaimed asphalt pavement (RAP) [20]. Foaming processes are the most common WMA technology [21]. One of these, the indirect foaming technique, includes the addition of synthetic zeolite, one of the most common additives for WMA production [22]. Synthetic zeolite is a porous mineral with crystallized water in its structure (ca. $20 \%$ ) composed of aluminosilicates of alkali metals [23]. This water is released for 6 or $7 \mathrm{~h}$ when the synthetic zeolite comes into contact with the preheated asphalt binder; it generates micro-foam, leading to an increase in the volume of the binder and reducing its viscosity [20], thereby increasing aggregate coating and the workability of the mixture [24].

Finally, it is necessary to solve the high consumption of raw materials and the waste generated by the replacement of deteriorated pavement. In this context, the replacement of raw materials by RAP in asphalt mixtures (WMA-RAP) achieves important benefits, because the use of virgin materials, both asphalt binder and aggregates, is reduced [25]. The use of RAP is an opportunity to reduce the impacts associated with extraction of the used material as well as the transportation of raw materials (energy consumption, carbon footprint and cost). Furthermore, the quantity of waste produced is reduced, helping to solve the final disposal problems of highway construction materials in landfills [26,27]. Some authors indicate that WMA technologies may help to increase the proportion of RAP in the 
asphalt mixture [28,29]. A larger proportion of RAP can be included in foamed WMA [27] than in other WMA technologies. In this context, the Road Pavement Research Group at Universidad de La Frontera has carried out a project to design and develop asphalt mixtures with greater energy efficiency and lower environmental impact. These are WMA and WMA-RAP mixtures which use a local natural zeolite (clinoptilolite-modernite type), extracted from the central zone of Chile, as the additive. In the present work, we studied five WMA types: two WMA with $0.3 \%$ and $0.6 \%$ natural zeolite content, and three WMA-RAP with $0.6 \%$ natural zeolite and different RAP contents $(10 \%, 20 \%$ and $30 \%)$. The control was a standard HMA. The first part of this study, published recently, concluded that these WMA and WMA-RAP performed well in rutting, cracking resistance, fatigue and moisture damage tests [30]. The present paper presents the second part of the study, the object of which is to assess emissions and energy consumption in the manufacturing process, including a cost analysis of the different mixtures.

\section{Materials and Methods}

\subsection{Materials and Mix Design}

One type of aggregate and one type of conventional asphalt binder (CA-24) were used in this research. The aggregates, obtained from fluvial sand deposits, are composed mainly of dolomite, basalt, dacite, andesite, rhyolite, sandstone, quartz and quartzite. A semi-dense asphalt mixture type IV-A-12 was used, which complies with Chilean specifications [31]. The physical properties of the aggregates according to Chilean standards are shown in Table 1. The aggregate gradation is presented in Figure 1. The properties of asphalt binder are shown in Table 2. The specific gravity of asphalt binder is $1040 \mathrm{~kg} / \mathrm{m}^{3}$, and the optimum mix temperature is $155^{\circ} \mathrm{C}$. The Marshall method was used to design the mixtures [32], appropriate for surface layers. This design method is the standard in Chile for asphalt pavements. As the objective is to promote massive use of this environmentally friendly alternative asphalt mixture, it was important follow the standards. The analyses of air voids (\%), flow $(0.25 \mathrm{~mm})$, stability $(\mathrm{kN})$ and voids in mineral aggregates $(\%)$ were performed according to Chilean specifications [31]. The optimum asphalt binder content was $5.4 \%$ of aggregate weight for the reference HMA mixture. This optimal binder content was used in the manufacture of all asphalt mixtures studied in this research.

Table 1. Physical properties of aggregates.

\begin{tabular}{ccc}
\hline Tests & Specifications & Results \\
\hline Coarse Aggregate & & \\
\hline Los Angeles abrasion loss (\%) & Max 25 & 18.4 \\
Disintegration in sodium sulphate (\%) & Max 12 & 2.4 \\
Crushed aggregates (\%) & Min 90 & 97.3 \\
Flakiness index (\%) & Max 10 & 0.1 \\
Static method adhesion (\%) & Min 95 & $>95$ \\
Dynamic method adhesion (\%) & Min 95 & $>95$ \\
Specific gravity (kg/m3) & - & 2661 \\
Absorption (\%) & - & 1.54 \\
\hline Fine Aggregate & & \\
\hline Plasticity index & Nonplastic & Nonplastic \\
Riedel-Weber adhesion & Min 0-5 & $0-9$ \\
Disintegration in sodium sulphate (\%) & Max 15 & 1.4 \\
Specific gravity (kg/m3) & - & 2629 \\
Absorption (\%) & - & 1.09 \\
\hline Combined Aggregate & & \\
\hline Soluble salts (\%) & Max 2 & 0.5 \\
Sand equivalent (\%) & Min 50 & 81 \\
\hline
\end{tabular}



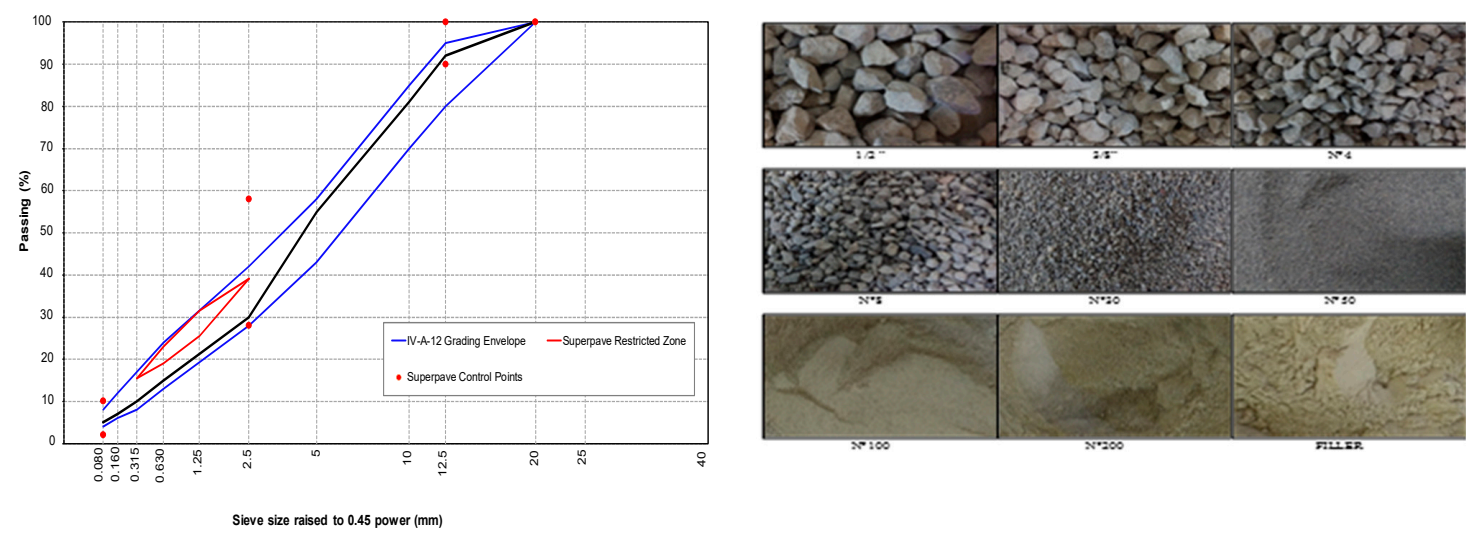

Figure 1. Grading curve asphalt mixture (IV-A-12).

Table 2. Properties of asphalt binder.

\begin{tabular}{ccc}
\hline Tests & Results & Specifications. \\
\hline Absolute viscosity at $60{ }^{\circ} \mathrm{C}, 300 \mathrm{~mm} \mathrm{Hg}(P)$ & 3730 & Min 2400 \\
Penetration at $25^{\circ} \mathrm{C}, 100 \mathrm{~g} .5 \mathrm{~s} .(0.1 \mathrm{~mm})$ & 60 & Min 40 \\
Ductility at $25^{\circ} \mathrm{C},(\mathrm{cm})$ & $>100$ & Min 100 \\
Spot test hep./xyl., $(\%$ xylene $)$ & $<30$ & Max 30 \\
Cleveland open cup flash point, $\left({ }^{\circ} \mathrm{C}\right)$ & $>232$ & Min 232 \\
Softening point $\mathrm{R} \& \mathrm{~B},\left({ }^{\circ} \mathrm{C}\right)$ & 52 & To be reported \\
Trichloroethylene solubility $(\%)$ & 99.8 & Min 99 \\
Penetration index & -0.2 & -1.5 a +1.0 \\
\hline RTFOT & & \\
Mass loss, $(\%)$. & 0.03 & Max 0.8 \\
Absolute viscosity at $60{ }^{\circ} \mathrm{C}, 300 \mathrm{~mm} \mathrm{Hg}(P)$ & 8800 & To be reported \\
Ductility at $25^{\circ} \mathrm{C}, 5 \mathrm{~cm} / \mathrm{min},(\mathrm{cm})$ & $>100$ & Min 100 \\
Durability index & 2.4 & Max 4.0 \\
\hline
\end{tabular}

The natural zeolite used in this research is a clinoptilolite-modernite type, obtained from the Quinamávida quarry in the VII Region of Chile. This mineral is found mainly in areas of volcanic activity, and Chile has large deposits. This type of natural zeolite is composed of aluminosilicates that have a three-dimensional arrangement with an open, porous structure [33], and can release crystallized water at $100{ }^{\circ} \mathrm{C}$ without affecting its internal structure. When the zeolite comes into contact with hot asphalt binder, the water is released and generates a micro-foam that allows the asphalt binder to involve the aggregates at a lower temperature.

Table 3 shows the characterization of the natural zeolite used in this study. Figure 2 shows the images of different contents of natural zeolite distributed in the asphalt binder obtained through a confocal microscope at two magnification levels. Epifluorescence images allow us to verify the dispersion of the natural zeolite in the binder. These images show that the zeolite-binder mixture is quite homogeneous for $1 \%, 5 \%$ and $10 \%$ additions (over weight of binder).

Table 3. Properties of Chilean natural zeolite.

\begin{tabular}{cc}
\hline Description & Chilean Natural Zeolite \\
\hline Chemical name & Calcium magnesium aluminosilicate hydrated \\
Grain size & $0-0.173$ mm \\
Main zeolitic component & Clinoptilolite-Modernite \\
Other components & Plagioclase, Smectite and Quartz \\
Colour & Ivory \\
\hline
\end{tabular}


Table 3. Cont.

\begin{tabular}{cc}
\hline Description & Chilean Natural Zeolite \\
\hline Chemical composition (\%) & $\mathrm{SiO}_{2}: 64.19 \mathrm{TiO}_{2}: 0.51 \mathrm{Al}_{2} \mathrm{O}_{3}: 11.65 \mathrm{Fe}_{2} \mathrm{O}_{3}: 2.53 \mathrm{MnO}: 0.03$ \\
Cation exchange capacity & $0.66 \mathrm{CaO}: 3,42 \mathrm{Na}_{2} \mathrm{O}: 0.75 \mathrm{~K}_{2} \mathrm{O}: 1.60 \mathrm{P}_{2} \mathrm{O}_{5}: 0.03 \mathrm{PxC}: 14.64$ \\
$86.82 \mathrm{a} 112.88 \mathrm{cmol} / \mathrm{kg}$ \\
Specific surface (Bet method) & $446 \mathrm{a} 480 \mathrm{~m}^{2} \mathrm{~g}^{-1}$ \\
Thermal stability & $<450{ }^{\circ} \mathrm{C}$ \\
Chemical stability & 8.9 \\
Density & $0.661 \mathrm{~g} / \mathrm{cm}^{3}$ \\
Natural moisture & $12.6 \%$ \\
\hline
\end{tabular}

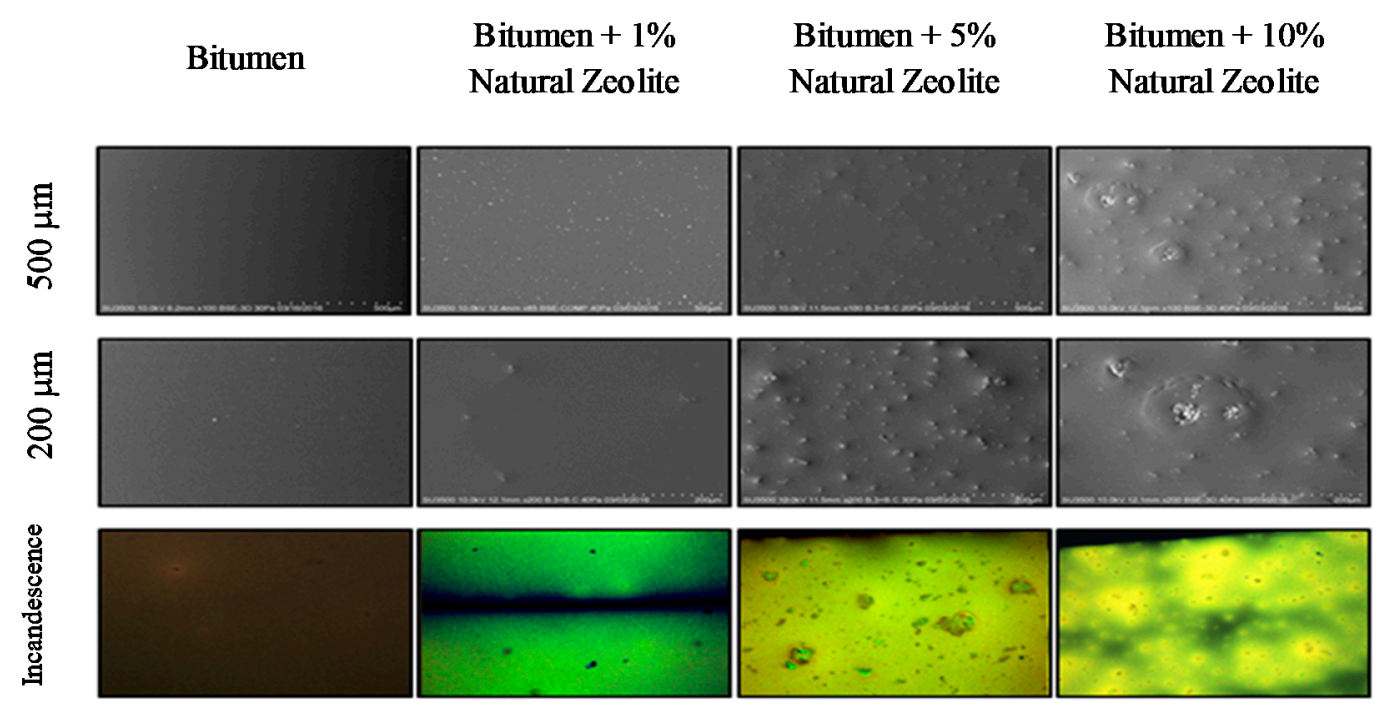

Figure 2. Homogeneity and incandescence of the bitumen with addition of natural zeolite.

The RAP used comes from milling works on Route 5, IX Region of Chile. In order to reduce the heterogeneity of the WMA-RAP mixtures, they were manufactured with two fractions of RAP, as recommended by Solaimanian and Tahmoressi [34]. The RAP fractions used were 0/5 mm and $5 / 20 \mathrm{~mm}$. Table 4 shows the RAP gradation and the bitumen content for both RAP fractions. The characteristics of binder recovered from the RAP before fractioning are shown in Table 5.

Table 4. Reclaimed asphalt pavement (RAP) gradation and bitumen content (after extraction).

\begin{tabular}{|c|c|c|}
\hline RAP Fraction (mm) & $0 / 5$ & $5 / 20$ \\
\hline Bitumen Content ( $\%$ by Weight of Mix) & 7.5 & 3.3 \\
\hline Sieve Size (mm) & \multicolumn{2}{|c|}{ Gradation (\% Passing) } \\
\hline 20 & 100 & 100 \\
\hline 12.5 & 100 & 73 \\
\hline 10 & 100 & 56 \\
\hline 5 & 100 & 29 \\
\hline 2.5 & 70 & 18 \\
\hline 0.63 & 35 & 11 \\
\hline 0.315 & 25 & 8 \\
\hline 0.16 & 19 & 5 \\
\hline 0.08 & 15 & 4 \\
\hline
\end{tabular}


Table 5. Characteristics of binder recovered from the RAP.

\begin{tabular}{cc}
\hline Tests & Results \\
\hline Penetration at $25^{\circ} \mathrm{C}, 100$ g. 5 s. $(0.1 \mathrm{~mm})$ & 10 \\
Fraas Breaking Point $\left({ }^{\circ} \mathrm{C}\right)$ & +3 \\
Softening Point R\&B, $\left({ }^{\circ} \mathrm{C}\right)$ & 55.6 \\
Brookfield Viscosity at $60{ }^{\circ} \mathrm{C}(\mathrm{Pa} \mathrm{s})$ & 30,883 \\
\hline
\end{tabular}

The asphalt mixtures evaluated are shown in Table 6 All these mixtures were evaluated for their resistance to moisture damage, low temperature cracking, fatigue and rutting, showing similar or better performance than the control HMA [30].

Table 6. Description of mixtures evaluated.

\begin{tabular}{ll}
\hline Nomenclature & Description \\
\hline P-155 & Control HMA, manufacturing temperature: $155^{\circ} \mathrm{C}$ \\
Z0.3-135 & WMA; Natural Zeolite content: $0.3 \%$ by weight of aggregates; manufacturing temperature $1355^{\circ} \mathrm{C}$ \\
Z0.6-135 & WMA; Natural Zeolite content: $0.6 \%$ by weight of aggregates; manufacturing temperature $135^{\circ} \mathrm{C}$ \\
PR10-155 & Control HMA-RAP, RAP content $10 \%$, manufacture production temperature: $155^{\circ} \mathrm{C}$ \\
R10-Z0.6-125 & WMA-RAP, RAP content $10 \%$, Natural Zeolite content: $0.6 \%$ manufacturing temperature $125{ }^{\circ} \mathrm{C}$ \\
PR20-155 & Control HMA-RAP, RAP content $20 \%$, manufacturing temperature: $155^{\circ} \mathrm{C}$ \\
R20-Z0.6-135 & WMA-RAP, RAP content $20 \%$, Natural Zeolite content: $0.6 \%$ manufacturing temperature $135{ }^{\circ} \mathrm{C}$ \\
PR-30-155 & Control HMA-RAP, RAP content $30 \%$, manufacturing temperature: $155^{\circ} \mathrm{C}$ \\
R30-Z0.6-145 & WMA-RAP, RAP content $30 \%$, Natural Zeolite content: $0.6 \%$ manufacturing temperature $145^{\circ} \mathrm{C}$ \\
\hline
\end{tabular}

\subsection{Test Methods for Gas Emission Evaluation}

To manufacture the WMA, aggregates and asphalt binder were heated to the mixing temperature according to Table 3 . In the case of WMA-RAP, the RAP temperature was $15^{\circ} \mathrm{C}$ and the raw aggregates had to be overheated to achieve the final manufacturing temperature (Table 7). To obtain each gas sample, $4 \mathrm{~kg}$ of asphalt mixture were manufactured, maintaining the dosage of each mixture. The mixtures were manufactured in a hermetic chamber for $5 \mathrm{~min}$, followed by $2 \mathrm{~min}$ resting time before gas capture. The gases $(500 \mathrm{~mL})$ were captured using a gas syringe and stored in hermetic Tedlar gas sample bags with a polypropylene valve (Figure 3). Three gas samples were taken for each asphalt mixture. It is important to note that the gas samples did not include the gases emitted during the combustion process, and only considered the gases generated by heating asphalt binder, RAP, aggregates and natural zeolite because the heating process was carried out without combustion in the laboratory.

Table 7. Overheating temperature of natural aggregates and binder dosage as a function of RAP content and final mixture temperature.

\begin{tabular}{|c|c|c|c|c|c|c|c|}
\hline \multicolumn{2}{|c|}{ Mixture of Aggregates } & \multicolumn{2}{|c|}{ Asphalt Binder Content (\%) } & \multicolumn{4}{|c|}{ Aggregate Temperature $\left({ }^{\circ} \mathrm{C}\right)$} \\
\hline Natural (\%) & RAP (\%) & $\begin{array}{c}\text { New } \\
\text { Binder }\end{array}$ & $\begin{array}{l}\text { RAP Binder } \\
\text { Contribution }\end{array}$ & \multicolumn{3}{|c|}{ WMA } & $\begin{array}{c}\text { HMA } \\
\text { (References) }\end{array}$ \\
\hline 100 & 0 & 5.4 & 0 & & 135 & & 155 \\
\hline 90 & 10 & 5.19 & 0.21 & 142 & & & 180 \\
\hline 80 & 20 & 4.98 & 0.43 & & 169 & & 200 \\
\hline 70 & 30 & 4.77 & 0.54 & & & 202 & 227 \\
\hline \multicolumn{4}{|c|}{ Manufacture temperature $\left({ }^{\circ} \mathrm{C}\right)$} & 125 & 135 & 145 & 155 \\
\hline
\end{tabular}



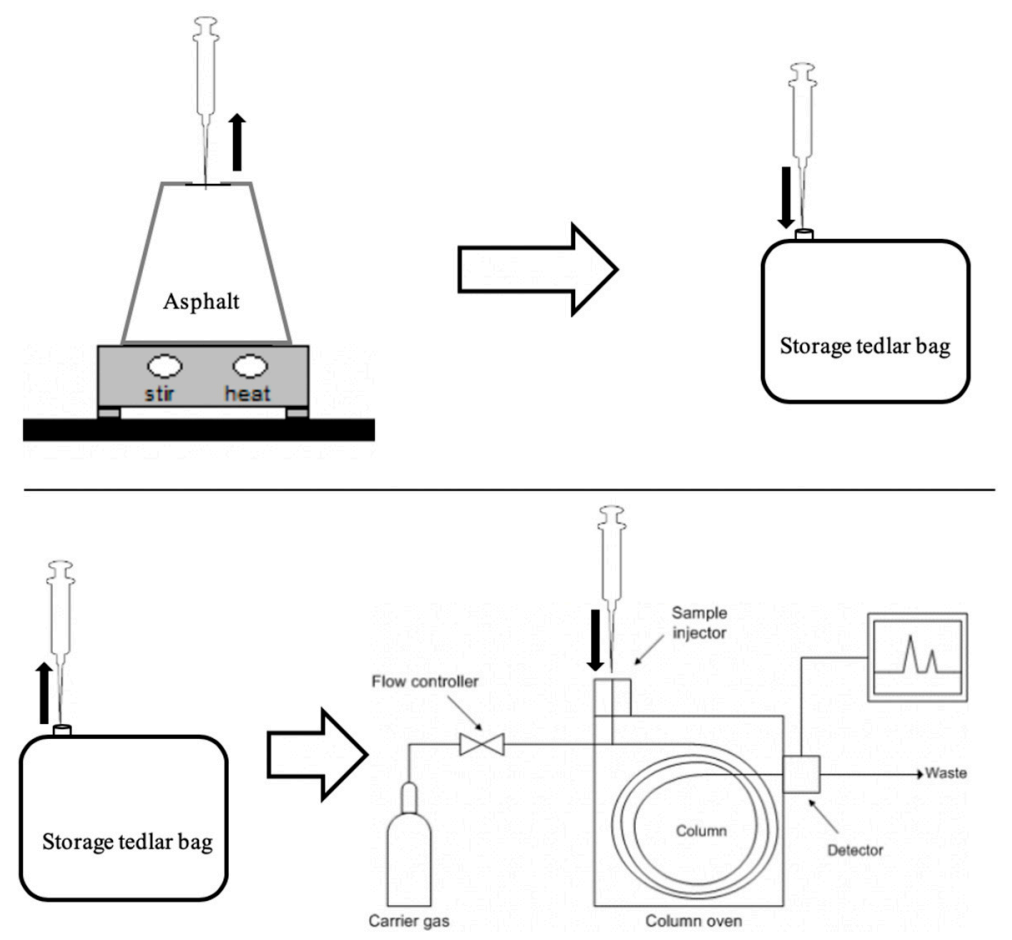

Figure 3. Diagram of fume capture and GEIS sampling systems.

A gas chromatograph with TCD (thermal conductivity detector), Clarus 580 Perkin Elmer, with a packed column 60/80 carboxeen $100015 \mathrm{ft} \times 1 / 8^{\prime \prime}(2.1 \mathrm{~mm}$ ID, internal diameter) was used to evaluate gas emissions. The gas samples were extracted from the gas storage bags and injected manually at a volume of $250 \mu \mathrm{L}$. The temperature of the detector was $250{ }^{\circ} \mathrm{C}$ and the injector temperature was $200^{\circ} \mathrm{C}$. Helium carrier gas was used, with a flow of $30 \mathrm{~mL} / \mathrm{min}$. The temperature ramp was $180^{\circ} \mathrm{C}$ for $4.50 \mathrm{~min}$. The working range was 0.05 to $1 \%$, Figure 3 . The gases evaluated were $\mathrm{CO}_{2}, \mathrm{CO}$ and $\mathrm{SO}_{2}$.

The methodology was divided into four phases (Figure 4). The first phase consisted of a review of studies related to the project, combined with visits to different asphalt mixing plants to become familiar with each stage involved in the manufacturing process in order to determine the most significant variables.

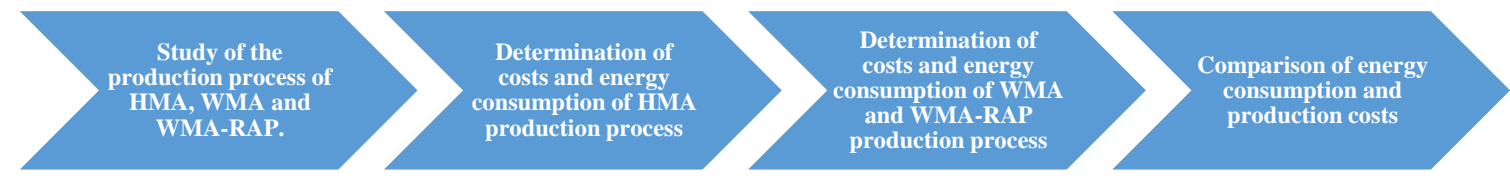

Figure 4. Four-phase model.

To complete the second phase, a cost table was generated by collecting data in the field provided by a local asphalt mixing company, incorporating the main costs related to the production of conventional asphalt mixtures. Additionally, energy consumption equations defined by Romier et al. [35] were used to determine the energy consumption during the production stage and to relate this variable to temperature changes (Equations (1)-(4)).

$$
C_{a g r} \times m_{a g r} \times\left(t_{a g r}-t_{a m b}\right)
$$

energy needed to heat aggregates (cal) (1)

$$
C_{a} \times\left(\frac{m_{a g r}}{m_{a g r}-\frac{u}{100} \times m_{a g r}}-1\right) \times m_{a g r} \times\left(100-t_{a m b}\right)
$$


energy needed to heat the water present in the aggregates (cal) (2)

$$
c l v \times\left(\frac{m_{a g r}}{m_{a g r}-\frac{u}{100} \times m_{a g r}}-1\right) \times m_{a g r}
$$

energy needed to vaporize water from aggregates (cal) (3)

$$
C_{v} \times\left(\frac{m_{a g r}}{m_{a g r}-\frac{u}{100} \times m_{a g r}}-1\right) \times m_{a g r} \times\left(t_{a g r}-100\right)
$$

energy needed to eliminate water vapor (cal) (4)

where: $C_{a g r}$ is the specific heat of aggregates $\left(\mathrm{cal} / \mathrm{kg}^{-1{ }^{\circ}} \mathrm{C}^{-1}\right) ; m_{a g r}$ is the mass of aggregates $(\mathrm{kg})$; $t_{a g r}$ is the aggregate heating temperature $\left({ }^{\circ} \mathrm{C}\right) ; t_{a m b}$ is the ambient temperature $\left({ }^{\circ} \mathrm{C}\right) ; \mathrm{C}_{a}$ is the specific heat of water; $\left(\mathrm{cal} / \mathrm{kg}^{-1 * 0} \mathrm{C}^{-1}\right) ; \mathrm{h}$ is the aggregate moisture content $(\%)$; clv is the latent heat of vaporization of the water $(\mathrm{cal} / \mathrm{kg}) ; C_{v}$ is the vapor-specific heat $\left(\mathrm{cal} / \mathrm{kg}^{-1 *{ }^{\circ}} \mathrm{C}^{-1}\right)$; and $\mathrm{t}_{\mathrm{agr}}$ is the aggregate heating temperature $\left({ }^{\circ} \mathrm{C}\right)$.

The parameters involved in calculating the energy and fuel consumption are shown in Tables 7 and 8 . The moisture content was fixed according to the average moisture content reported by the production plant. To determine the cost and energy consumption of WMA and WMA-RAP, the cost table of the conventional asphalt mixture (previously generated and validated with information provided by the mixing plant) was modified by the inclusion of the new costs according to the different amounts of zeolites and RAP. In this stage, the energy consumption was calculated by the Romier equations, varied according to the changes in the manufacturing temperature. These modifications were caused by the variation in fuel consumption, and in the amount of virgin raw materials (binder and aggregates) used for each WMA-RAP mixture since these were reduced as a function of the amount of RAP included. Finally, the cost tables were compared with the reference mixture. The fuel consumption was calculated by converting the energy consumption to fuel, based on the heating power of fuel oil. The production costs of the different proposed mixtures were obtained by assessing the energy consumption and the costs associated with the raw materials and additive (natural zeolite).

Table 8. Parameters involved in energy and cost consumption.

\begin{tabular}{ccc}
\hline Parameter & Value & Unit \\
\hline${ }^{1}$ Specific heat of aggregates $\left(C_{a g r}\right)$ & 850 & $\mathrm{~J} /\left(\mathrm{kg} *{ }^{*} \mathrm{C}\right)$ \\
Specific heat of water $\left(C_{a}\right)$ & 4200 & $\mathrm{~J} /\left(\mathrm{kg} *{ }^{\circ} \mathrm{C}\right)$ \\
Specific heat of steam $\left(C_{v)}\right.$ & 1850 & $\mathrm{~J} /\left(\mathrm{kg} *{ }^{\circ} \mathrm{C}\right)$ \\
Latent heat of water vaporization $(c l v)$ & $2,250,000$ & $\mathrm{~J} /\left(\mathrm{kg} *{ }^{\circ} \mathrm{C}\right)$ \\
Moisture content of aggregates $(h)$ & 3 & $\% \%$ \\
Ambient temperature $\left(t_{a m b}\right)$ & 15 & ${ }^{\circ} \mathrm{C}$ \\
Heating temperature of aggregates $\left(t_{a g r}\right)$ & 155 & ${ }^{\circ} \mathrm{C}$ \\
Heating temperature of bitumen & 155 & ${ }^{\circ} \mathrm{C}$ \\
2 Heating power of fuel oil & $9,762,000$ & $\mathrm{Cal} / \mathrm{kg}$ \\
2 Density of fuel oil & 0.9994 & $\mathrm{~kg} / \mathrm{L}$ \\
Assessed quantity of mixture & 1000 & $\mathrm{~kg}$ \\
\hline
\end{tabular}

${ }^{1}$ The Specific heat of granitic aggregates [36]; ${ }^{2}$ The information about fuel oil was extracted from the fuel supplier's certificate.

\section{Analysis of Results}

\subsection{Gas Emissions}

Before we analyze the results, it is important to remember that this study considers only the emissions generated by heating the asphalt binder in contact with the raw aggregates, and, in some cases, natural zeolite and varying percentages of RAP (i.e., combustion emissions produced by aggregate heating, such as those produced during the production process in asphalt plants, were isolated). In this 
context, it is observed that the $\mathrm{SO}_{2}$ emission level was outside the detection ranges for all the mixtures studied. This implies that the $\mathrm{SO}_{2}$ emissions were less than $0.05 \%$, considered as null for all the mixtures evaluated. These results may be because $\mathrm{SO}_{2}$ is generated by the combustion process [16] and is highly dependent on fuel type, with fuel oil and recycled fuel oil causing the most pollution. On the other hand, natural gas seems to be an environmentally friendly fuel alternative, since it has a lower sulphur content [16]. This agrees with the results obtained by Lecomte et al. [37], who compared the $\mathrm{SO}_{2}$ emissions between $\mathrm{HMA}\left(180{ }^{\circ} \mathrm{C}\right)$ and WMA foam $\left(125-130{ }^{\circ} \mathrm{C}\right)$. They observed a $35 \%$ reduction in fuel consumption, obtaining a reduction in $\mathrm{SO}_{2}$ emissions between $25 \%$ and $30 \%$. On the other hand, Hurley et al. [38] analyzed the natural gas consumption in three WMA mixtures (Evotherm ${ }^{\circledR}$, Aspha-min ${ }^{\circledR}$ and Sasobit ${ }^{\circledR}$ ). The fuel consumption results were $+15.4 \%,-8.8 \%$ and $-17.9 \%$ (Control, HMA, WMA), respectively, while the $\mathrm{SO}_{2}$ emissions were $+54 \%,-83 \%$ and $-83 \%$ (Control, HMA, WMA), respectively. These results suggest that fuel consumption is the greatest contributing factor to $\mathrm{SO}_{2}$ emissions.

Similar levels of $\mathrm{CO}$ emissions were observed between HMA and WMA. The reduction percentage of CO concentration was $2 \%$ for Z-0.3-135, while for Z-0.6-135 the CO emission level was similar to that of P-155 (Figure 5). When HMA-RAP is compared to WMA-RAP (Figure 5), reductions in CO emissions of $6 \%, 5 \%$ and $4 \%$ were detected (R10-Z0.6-125, R20-Z0.6-135 and R30-Z0.6-145 respectively). Some researchers suggest that $\mathrm{CO}$ emissions are associated with fuel consumption and depend on the type of fuel, reporting that WMA manufactured in a plant powered with natural gas emitted eighteen times less CO than a plant with fuel oil under the same conditions [3]. However, Anderson et al. [39] concluded that $\mathrm{CO}$ emissions are more closely related to burner maintenance. Lecomte et al. [37] obtained CO reductions of around $8 \%$ when comparing measurements made in the chimney of the mixing plant during the manufacture of HMA $\left(180^{\circ} \mathrm{C}\right)$ and WMA foam mixture $\left(125-130^{\circ} \mathrm{C}\right)$. These findings are consistent with this study, as the effects of fuel burning or burner maintenance are not considered for any of the mixtures evaluated. However, it is remarkable that $\mathrm{CO}$ emissions are not correlated exclusively with fuel burning, since $\mathrm{CO}$ emissions were detected in this study.

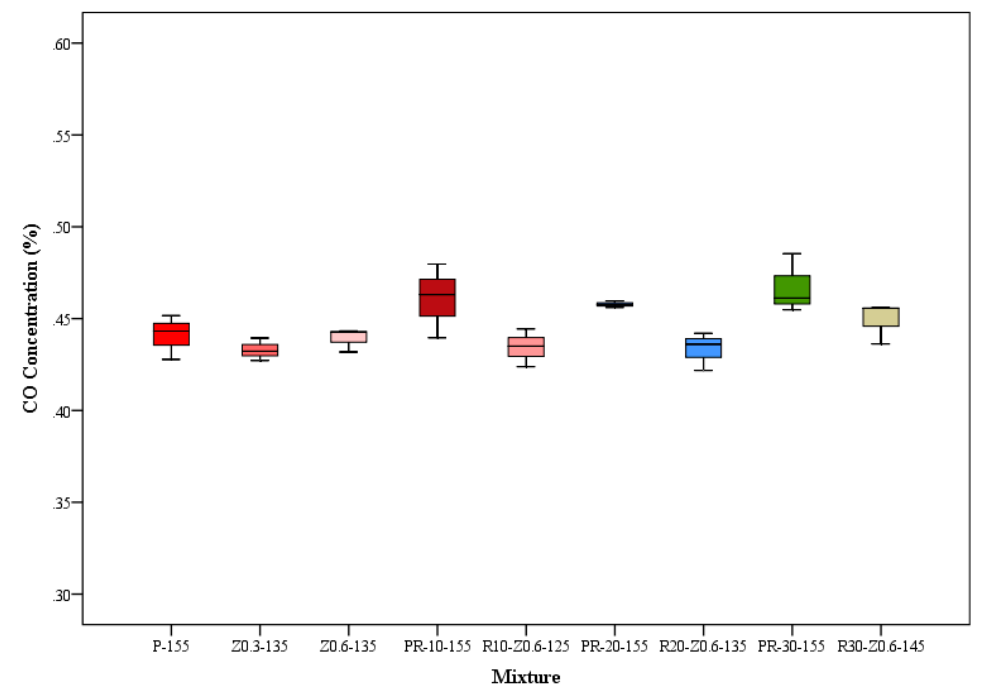

Figure 5. CO concentration (\%).

Additionally, the reference mixtures with RAP (PR-10-155, PR-20-155, PR-30-155) showed more $\mathrm{CO}$ emissions than the reference mixture without RAP (P-155). However, the reduction in CO emissions in WMA-RAP manufactured at a lower temperature than the reference mixtures with RAP was larger than the difference between WMA and the reference mixture without RAP (Figure 5). 
In the analysis of $\mathrm{CO}_{2}$ emissions, $90 \%$ were found to occur directly during the asphalt mixing process [14]. The complete production process includes aggregate heating, asphalt heating, and mixing. In these stages, the carbon emissions observed reached values of $67 \%, 14 \%$ and $12 \%$, respectively [14]. This study focuses on the third stage, the mixing process. The results for $\mathrm{CO}_{2}$ emissions showed a reduction for all mixtures evaluated; emissions were higher for WMA-RAP (Figure 6). These results are similar to those presented by Sharma et al. [40], who observed $\mathrm{CO}_{2}$ emission reductions of between $2.5 \%$ and $35 \%$, respectively, in a comparison of HMA $\left(180{ }^{\circ} \mathrm{C}\right)$ with WMA $\left(140{ }^{\circ} \mathrm{C}\right)$ with $2 \%-6 \%$ addition of synthetic zeolite (over binder content). Lecomte et al. [37] also observed $\mathrm{CO}_{2}$ emission reductions of around $35 \%$ in a comparison between HMA manufactured at $180{ }^{\circ} \mathrm{C}$ and WMA foam at $125-130{ }^{\circ} \mathrm{C}$, both measured in the chimney of the mixing plant. Comparable results were obtained by Mallik et al. [12], who reported a direct reduction in $\mathrm{CO}_{2}$ emissions of around $32 \%$ by decreasing the mixing temperatures by between 10 and $30^{\circ} \mathrm{C}$.

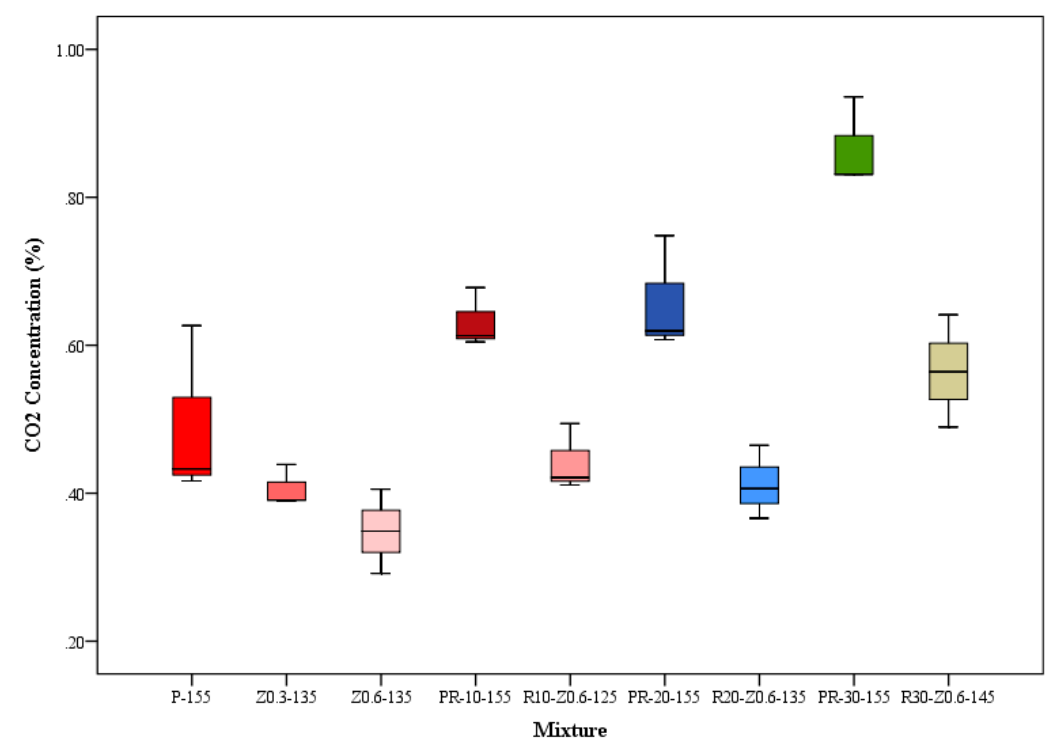

Figure 6. $\mathrm{CO}_{2}$ concentration (\%).

In this study, the $\mathrm{CO}_{2}$ emission reductions were obtained by comparing HMA manufactured at $155{ }^{\circ} \mathrm{C}$ with WMA at $135{ }^{\circ} \mathrm{C}$. The emissions were reduced by $17 \%$ and $23 \%$, respectively, with the addition of $0.3 \%$ and $0.6 \%$ natural zeolite (Figure 6). Larger reductions were obtained in WMA-RAP with the addition of $0.6 \%$ natural zeolite (R10-Z0.6-125, R20-Z0.6-135, R30-Z0.6-145), which were compared with the reference mixtures manufactured with RAP (PR-10-155, PR-20-155, PR-30-155). These WMA-RAP mixtures showed reductions in $\mathrm{CO}_{2}$ emissions in the range of $30 \%$ to $37 \%$, the largest reduction being obtained with R20-Z0.6-135 (Figure 6). This may be related to the results obtained by Giani et al. [41], who indicated that WMA produced using RAP instead of virgin raw materials may mean a reduction in $\mathrm{CO}_{2}$ emissions of approximately $12 \%$ over the whole life cycle.

\subsection{Energy Consumption}

Energy consumption assessment of the production processes of different pavement types may constitute an important tool for engineers and legislators in selecting the type of pavement and technology to use in infrastructure design, in terms of both environmental impact and economic investment [2]. In this context, the manufacture of HMA requires higher energy consumption during asphalt mixing and aggregate heating; the latter process accounts for $53 \%$ of energy consumption [2]. Several researchers have concluded that the lower production temperature of WMA technologies may reduce the energy consumption compared to HMA [42,43]. This is consistent with the results shown in Figure 7, which show a reduction in energy consumption due to the lower production 
temperature. The reference HMA was produced at $155^{\circ} \mathrm{C}$, while the study mixtures were produced at lower temperatures $\left(125^{\circ} \mathrm{C}, 135^{\circ} \mathrm{C}\right.$ and $\left.145^{\circ} \mathrm{C}\right)$. These temperature reductions account for decreases in energy consumption of $13 \%, 9 \%$ and $5 \%$, respectively. These findings are similar to those reported by Anderson et al. [39], who described an energy saving of about 10\% using WMA with water-injection foaming systems. Croteau and Tessier [10], in their study of the WMA state-of-practice, indicated energy savings ranging from 20 to 35\% according to the reports of WMA trials in an asphalt plant. Similarly, Harder et al. [44] observed reductions in energy consumption of between $10 \%$ and $30 \%$. These variations are dependent on the WMA system, moisture content of the aggregates and the type/efficiency of the plant. Expressed in terms of kcal, a reduction of $2051 \mathrm{kcal} / \mathrm{ton}$ per $10{ }^{\circ} \mathrm{C}$ decrease in temperature is observed. A similar result was reported by Peinado et al. [42], who noted an extra energy demand of about $2253 \mathrm{Kcal}$ for an increase of $10^{\circ} \mathrm{C}$ in the mixture temperature.

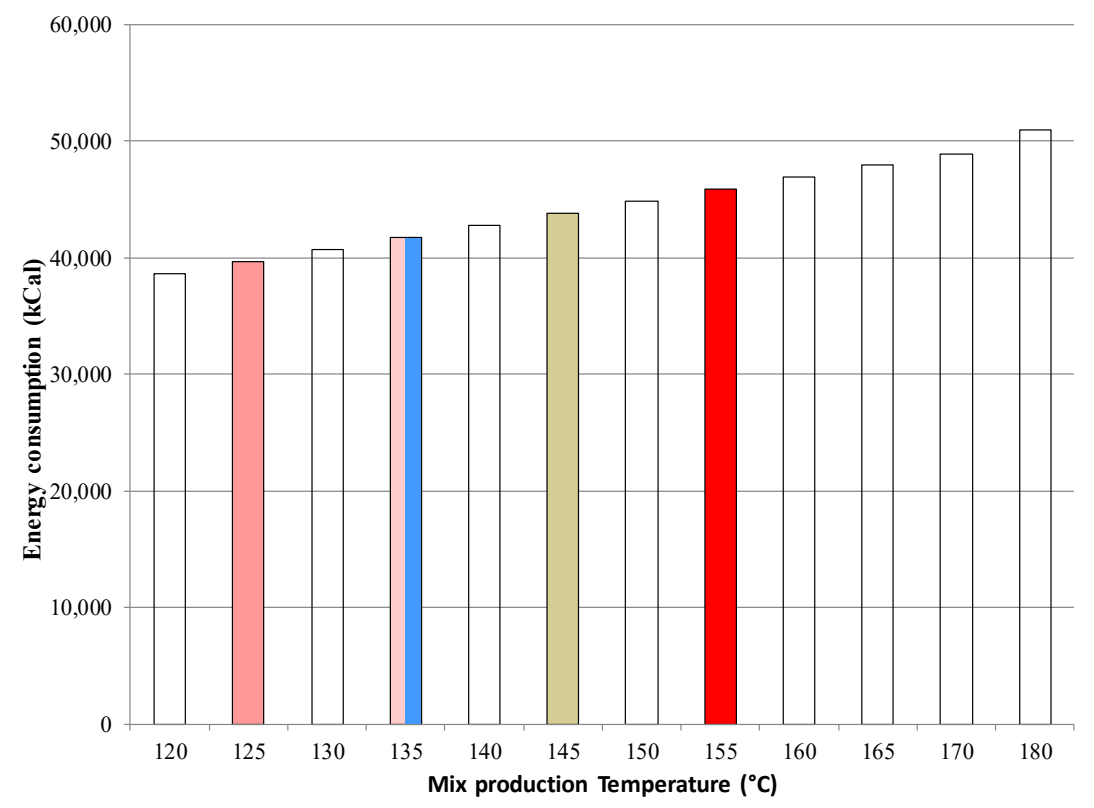

Figure 7. Energy consumption in reference to production temperature.

\subsection{Evaluation of Production Cost}

Energy savings are related to cost reductions because they imply a reduction in fuel consumption. Several researchers have reported economic benefits from the use of WMA. The different quantities of fuel required to produce all mixtures evaluated in this study were calculated, based on the energy consumption results of the asphalt mixtures produced at different temperatures and the heating power of the fuel. Parameters such as ambient temperature $\left(15^{\circ} \mathrm{C}\right)$, aggregate moisture content $(3 \%)$ and RAP moisture content $(0.3 \%)$ were fixed (Table 8$)$, since the focus of the present study was on the energy and cost savings achievable by reducing the manufacturing temperature during the production stage. A reduction in fuel consumption of about $10 \%$ was observed for WMA at $135{ }^{\circ} \mathrm{C}$, while for WMA-RAP the reduction in fuel consumption reached 15\% for R10-Z0.6-125, R20-Z0.6-135 and R30-Z0.6-145 (Figure 8). These results are similar to those reported by Anderson et al., who indicated that a temperature reduction of $27^{\circ} \mathrm{C}$ resulted in an average fuel saving of $22 \%$, with data drawn from 13 projects [39]. 


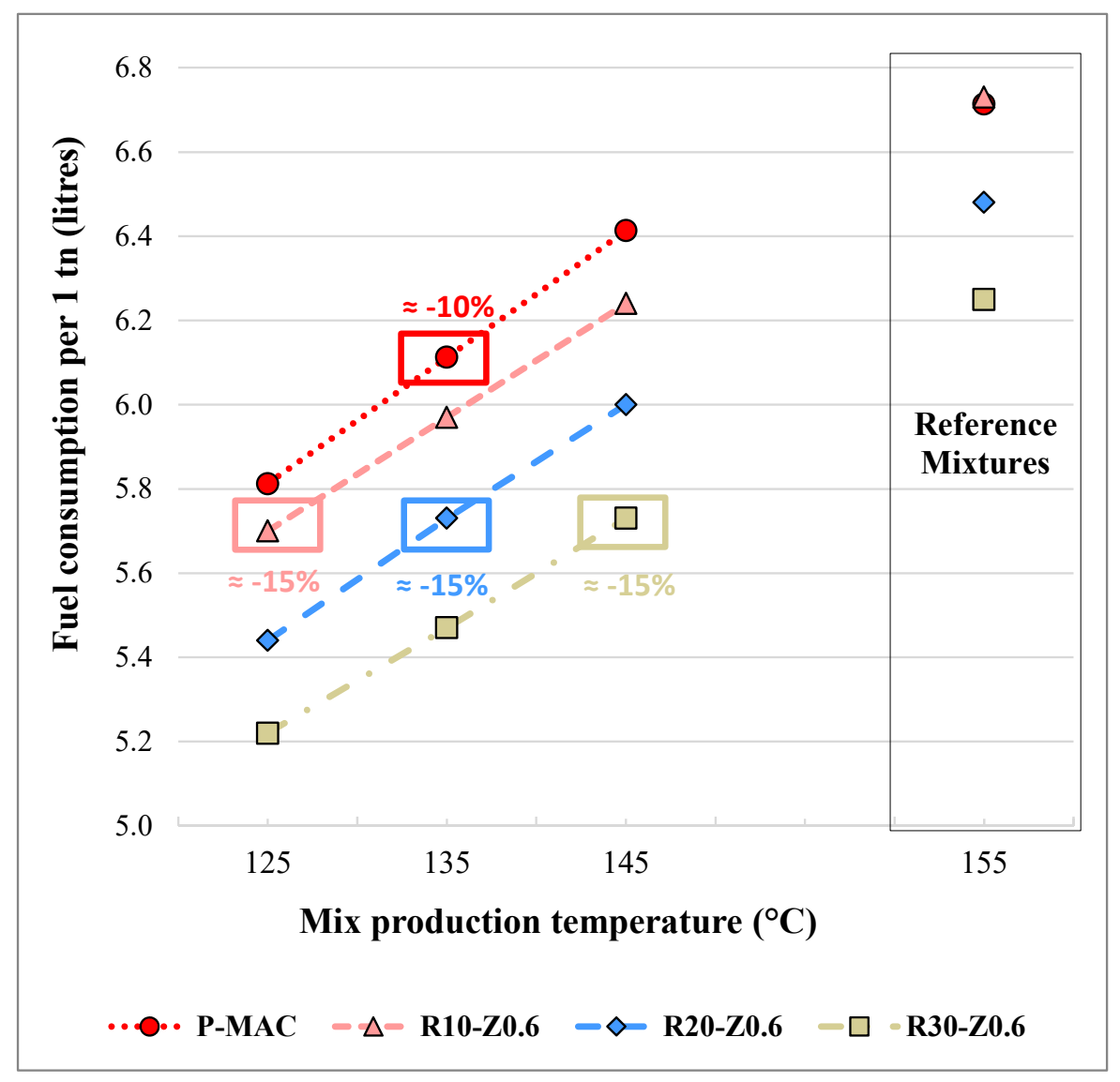

Figure 8. Comparison of fuel consumption per 1 ton of mixture production.

The cost evaluation of WMA with the addition of natural zeolite included the cost of the additive and the savings related to reduced fuel consumption. For the WMA-RAP with natural zeolite, the cost evaluation considered the cost of the additive and the savings due to reduced fuel consumption and raw materials (aggregates and asphalt binder). The cost evaluations consider the production temperature for all the mixtures evaluated, including the aggregate overheating temperature required for the WMA with RAP, as well as the reduced consumption of virgin asphalt binder due to the incorporation of RAP (Table 7).

The current cost of natural zeolite reported by the supplier is US\$1.03 per $\mathrm{kg}$. This is a high cost, much higher than the cost of lime (US\$0.11 per kg), probably due to the lack of development of this industry. The production process of natural zeolite includes the same steps as the production of lime: extraction of natural stone, grinding, sieving and finally packaging for commercialization; however, lime production requires an important extra step: mineral calcination at $900{ }^{\circ} \mathrm{C}$. This process implies a major additional cost that is not required to obtain natural zeolite. Nevertheless, the cost of lime continues to be considerably lower than that of natural zeolite. In consideration of the above, two cost evaluations were carried out based on two scenarios: the current situation, when the cost of natural zeolite is US\$1.03 per kg; and a hypothetical future situation, in the expectation that the natural zeolite industry is likely to grow to meet demand, when the cost of natural zeolite will fall to a similar level to that of lime (US\$0.11 per $\mathrm{kg}$ ). The results shown in Figure 9 indicate that in the current situation, the production cost of manufacturing WMA is higher than the production cost of HMA by a factor ranging from $5 \%$ for WMA with $0.3 \%$ of natural zeolite to $12 \%$ for WMA with $0.6 \%$ of natural zeolite. These results were higher than the cost of the reference mixture (P-155) because the savings in fuel costs were lower than the extra cost of the additive. Similar findings were reported by EAPA, which described the production cost of WMA as being similar to or slightly higher than that of HMA [45]. 
Almeida et al. [46] obtained similar results, comparing rough asphalt concrete with WMA $\left(\right.$ Sasobit $\left.{ }^{\circledR}\right)$; they reported little difference in the total costs of the two mixtures. When the hypothetical situation projected above is analyzed, the cost of WMA with $0.3 \%$ and $0.6 \%$ natural zeolite may be similar to that of HMA.

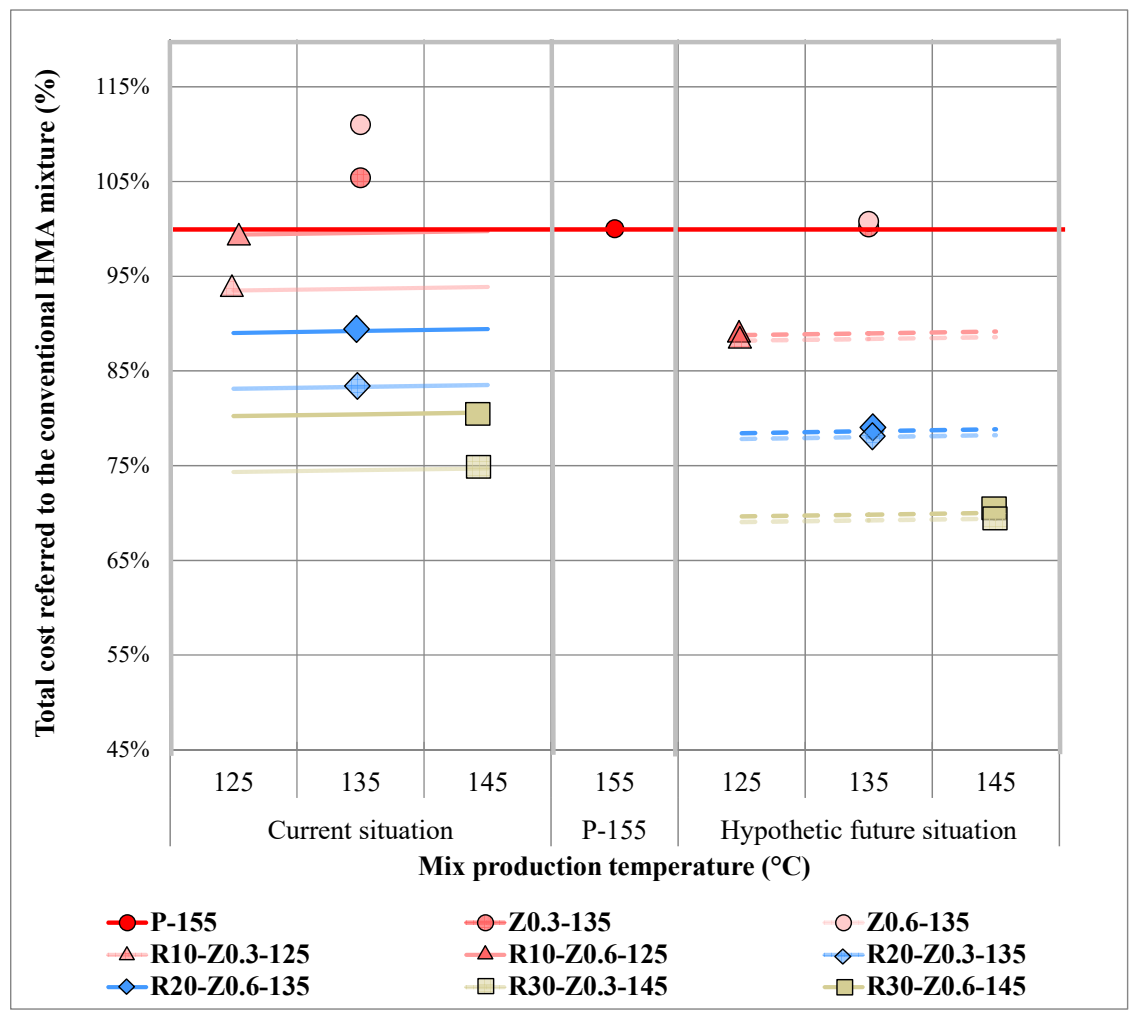

Figure 9. Production cost evaluation for warm mix asphalt (WMA) with natural zeolite addition considering 1 ton of mixture, in the current situation and a hypothetical future situation.

When the cost of WMA with the addition of natural zeolite and RAP is analyzed (Figure 9), all the asphalt mixtures evaluated in this study present reduced costs. In the current situation, WMA with $30 \%$ RAP and $0.3 \%$ natural zeolite presented cost savings of about $25 \%$, while the cost savings for WMA with $30 \%$ RAP and $0.6 \%$ natural zeolite were $19 \%$ (both manufactured at $145{ }^{\circ} \mathrm{C}$ ). For WMA with $10 \%$ RAP produced at $125^{\circ} \mathrm{C}$, the cost savings were $7 \%$ and $1 \%$ for the addition of $0.3 \%$ and $0.6 \%$ of natural zeolite respectively. Finally, if a balance is sought between incorporating RAP and reducing temperature, the best alternative might be WMA with $20 \%$ RAP produced at $135^{\circ} \mathrm{C}$, which gives cost savings of $17 \%$ and $11 \%$ for the addition of $0.3 \%$ and $0.6 \%$ natural zeolite respectively. Analyzing the WMA-RAP mixtures in the hypothetical future situation, the cost savings may be higher, achieving a cost reduction of 30\% for R30-Z0.6-145, 21\% for R20-Z0.6-135 and 11\% for R10-Z0.6-125 (Figure 9). These results are consistent with the report by Kristjánsdóttir et al. [43], who showed that RAP incorporation may be a good approach to cost savings; they concluded that in the project evaluated, increasing the RAP content from $25 \%$ to $40 \%$ would result in a net saving of US\$4.55/ton.

\section{Conclusions}

The present study focused on the gas emissions, energy consumption and production costs of WMA and WMA-RAP, in comparison with a reference mixture. In terms of gas emissions, all the WMA showed reductions in direct $\mathrm{CO}_{2}$ emissions of $17 \%$ and $23 \%$, respectively with the addition of $0.3 \%$ and $0.6 \%$ natural zeolite. The $\mathrm{CO}_{2}$ reductions for WMA-RAP were higher, reaching $37 \%$ for WMA-RAP with $20 \%$ RAP manufactured at $135^{\circ} \mathrm{C}$ and $35 \%$ for WMA-RAP with $30 \%$ RAP manufactured at $145^{\circ} \mathrm{C}$. 
The reductions in $\mathrm{CO}$ emissions were smaller than those achieved for $\mathrm{CO}_{2}$ : for WMA, the $\mathrm{CO}$ reduction was not statistically significant, whereas for WMA-RAP the CO emissions decreased by nearly $6 \%$. On this point, it is remarkable that the $\mathrm{CO}$ emissions are not only correlated to fuel burning; in this research $\mathrm{CO}$ emissions were detected although the fuel burning process was excluded. For all asphalt mixtures evaluated, $\mathrm{SO}_{2}$ emissions were out of the detection ranges $(0.05 \%)$; this could be because $\mathrm{SO}_{2}$ is generated by the combustion process and is highly dependent on fuel type, which was not considered here.

Reductions in energy consumption were found in the range of $5 \%$ to $13 \%$, similar to the reductions reported by other researchers.

Finally, in the cost evaluation, the cost reduction for WMA achieved by reduced fuel consumption was not enough to compensate the current additional cost of the additive; these mixtures are still slightly more expensive than the reference mixture. The situation for WMA-RAP was different: production cost savings close to $25 \%$ were achieved for the mixtures with $30 \%$ RAP and $0.3 \%$ natural zeolite.

Our results show that all the asphalt mixtures evaluated presented reduced gas emissions and energy/fuel consumption, with a cost similar to the control HMA. In addition, if the mixtures are manufactured with RAP, the benefits will be greater thanks to the energy and cost savings; mixtures containing RAP also offer environmental benefits, which include lower emissions and the use of recycled asphalt pavement materials.

Author Contributions: L.A.M.-P.: experimental work and data analysis; E.S.-A.: methodology, investigation, data analysis, review and editing, G.A.V.-V.: project administration, investigation, data analysis, review and editing, A.T.C.-F.: methodology, investigation, data analysis, writing-original draft preparation, review and editing. All authors have read and agreed to the published version of the manuscript.

Funding: This research was funded by Comisión Nacional de Investigación Ciencia y Tecnología (CONICYT) conducted within the framework of the FONDEF IDEA Grant No ID15I10235; and by Universidad de La Frontera through DIUFRO Grant N DI18-0053.

Conflicts of Interest: The authors declare no conflict of interest. The funders had no role in the design of the study; in the collection, analyses, or interpretation of data; in the writing of the manuscript, or in the decision to publish the results.

\section{References}

1. Chappat, M.; Bilal, J. The Environmental Road of the Future: Life Cycle Analysis; Colas SA: Paris, France, 2003; Volume 9, pp. 1-34.

2. Zapata, P.; Gambatese, J.A. Energy Consumption of Asphalt and Reinforced Concrete Pavement Materials and Construction. J. Infrastruct. Syst. 2005, 11, 9-20. [CrossRef]

3. Thives, L.P.; Ghisi, E. Asphalt mixtures emission and energy consumption: A review. Renew. Sustain. Energy Rev. 2016, 72, 473-484. [CrossRef]

4. Autelitano, F.; Bianchi, F.; Giuliani, F. Airborne emissions of asphalt/wax blends for warm mix asphalt production. J. Clean. Prod. 2017, 164, 749-756. [CrossRef]

5. Woszuk, A.; Zofka, A.; Bandura, L.; Franus, W. Effect of zeolite properties on asphalt foaming. Constr. Build. Mater. 2017, 139, 247-255. [CrossRef]

6. Miller, T.D.; Bahia, H.U. Sustainable Asphalt Pavements: Technologies, Knowledge Gaps and Opportunities; University of Wisconsin Madison: Madison, WI, USA, 2009.

7. Gasthauer, E.; Mazé, M.; Marchand, J.P.; Amouroux, J. Characterization of asphalt fume composition by GC/MS and effect of temperature. Fuel 2008, 87, 1428-1434. [CrossRef]

8. Jullien, A.; Gaudefroy, V.; Ventura, A.; de La Roche, C.; Paranhos, R.; Monéron, P. Airborne Emissions Assessment of Hot Asphalt Mixing: Methods and limitations. Road Mater. Pavement Des. 2010, 11, 149-169. [CrossRef]

9. Qian, S.L.; Wang, F. The Experimental Study on the Road Asphalt Fumes Inhibitors. Adv. Mater. Res. 2012, 413, 472-476. [CrossRef]

10. Croteau, J.; Tessier, B. Warm mix asphalt paving technologies: A road builder's perspective. In Proceedings of the 2008 Annual Conference of the Transportation Association of Canada, Whistler, BC, Canada, 21-24 September 2008; pp. 1-12. 
11. Jamshidi, M.; Hamzah, O.; You, Z. Performance of Warm Mix Asphalt containing Sasobit ${ }^{\circledR}$ : State-of-the-art. Constr. Build. Mater. 2013, 38, 530-553. [CrossRef]

12. Mallick, R.B.; Bergendahl, J. A laboratory study on $\mathrm{CO}_{2}$ emission from asphalt binder and its reduction with the use of warm mix asphalt. Int. J. Sustain. Eng. 2009, 2, 275-283. [CrossRef]

13. Ahmad, I.; Shakirullah, M.; ur Rehman, H.; Ishaq, M.; Khan, M.A.; Shah, A.A. NMR analysis of cracking products of asphalt and assessment of catalyst performance. Energy 2009, 34, 127-133. [CrossRef]

14. Peng, B.; Cai, C.; Yin, G.; Li, W.; Zhan, Y. Evaluation system for $\mathrm{CO}_{2}$ emission of hot asphalt mixture. J. Traffic Transp. Eng. (Engl. Ed.) 2015, 2, 116-124. [CrossRef]

15. Brandt, H.C.A.; de Groot, P.C. A laboratory rig for studying aspects of worker exposure to bitumen fumes. Am. Ind. Hyg. Assoc. J. 1999, 60, 182-190. [CrossRef] [PubMed]

16. West, R.; Rodezno, C.; Julian, G.; Prowell, B.; Frank, B.; Osborn, L.V.; Kriech, T. NCHRP Report 779. Field Performance of Warm Mix Asphalt Technologies; Transportation Research Board of the National Academies: Washington, DC, USA, 2014.

17. Autelitano, F.; Giuliani, F. Analytical assessment of asphalt odor patterns in hot mix asphalt production. J. Clean. Prod. 2018, 172, 1212-1223. [CrossRef]

18. Adbullah, M.E.; Zamhari, K.A.; Hainin, M.R.; Oluwasola, E.A.; Yusoff, N.I.M.; Hassan, N.A. High temperature characteristics of warm mix asphalt mixtures with nanoclay and chemical warm mix asphalt modified binders. J. Clean. Prod. 2016, 122, 326-334.

19. Hasan, M.R.M.; You, Z.; Yang, X. A comprehensive review of theory, development, and implementation of warm mix asphalt using foaming techniques. Constr. Build. Mater. 2017, 152, 115-133. [CrossRef]

20. Prowell, B.D. Warm Mix Asphalt, the International Technology Scanning Program Summary Report; American Trade Initiatives: Alexandria, Egypt, 2007; p. 21.

21. Iwański, M.; Chomicz-Kowalska, A.; Maciejewski, K. Application of synthetic wax for improvement of foamed bitumen parameters. Constr. Build. Mater. 2015, 83, 62-69. [CrossRef]

22. Sengoz, B.; Topal, A.; Gorkem, C. Evaluation of natural zeolite as warm mix asphalt additive and its comparison with other warm mix additives. Constr. Build. Mater. 2013, 43, 242-252. [CrossRef]

23. Rubio, M.C.; Martínez, G.; Baena, L.; Moreno, F. Warm Mix Asphalt: An overview. J. Clean. Prod. 2012, 24, 76-84. [CrossRef]

24. Barthel, W.; Marchand, J.-P.; von Devivere, M. Warm asphalt mixes by adding a synthetic zeolite. In Proceedings of the 3rd Eurasphalt \& Eurobitume Congress, Vienna, Austria, 12-14 May 2004; Volume 1.

25. Adnan, M.; Shafi, M.; Sharma, A. Laboratory study on use of RAP in WMA pavements using rejuvenator. Constr. Build. Mater. 2018, 168, 61-72.

26. Horvath, A. Life-Cycle Environmental and Economic Assessment of Using Recycled Materials for Asphalt Pavements; University of California Transportation Center: Berkeley, CA, USA, 2003.

27. Mallick, R.B.; Kandhal, P.S.; Bradbury, R.L. Using warm mix asphalt technology to incorporate high percentage of reclaimed asphalt pavement (RAP) material in asphalt mixtures. Transp. Res. Rec. J. Transp. Res. Board 2008, 2051, 71-79. [CrossRef]

28. Al-Qadi, I.L.; Elseifi, M.; Carpenter, S.H. Reclaimed Asphalt Pavement-A Literature Review; Illinois Center for Transportation: Rantoul, IL, USA, 2007.

29. Farooq, M.A.; Mir, M.S. Use of reclaimed asphalt pavement (RAP) in warm mix asphalt (WMA) pavements: A review. Innov. Infrastruct. Solut. 2017, 2,1-9. [CrossRef]

30. Valdes-Vidal, G.; Calabi-Floody, A.; Sanchez-Alonso, E. Performance evaluation of warm mix asphalt involving natural zeolite and reclaimed asphalt pavement (RAP) for sustainable pavement construction. Constr. Build. Mater. 2018, 174, 576-585. [CrossRef]

31. Públicas, M.D.; de Vialidad, D. Manual de Carreteras Volumen 5 Especificaciones Técnicas Generales de Construcción; Ministerio de Obras Públicas: Santiago, Chile, 2017.

32. Ministerio de Obras; de Vialidad, D. Manual de Carreteras Volumen 8 Especificaciones y métodos de muestreo, ensaye y control, Test method 8.302.40. In Asfaltos Método Para Determinar La Resistencia a La Leformación Plástica de de Mezclas Asfálticas Utilizando el Aparato Marshall; Ministerio de Obras Públicas: Santiago, Chile, 2017.

33. Woszuk, A.; Franus, W. A Review of the Application of Zeolite Materials in Warm Mix Asphalt Technologies. Appl. Sci. 2017, 7, 293. [CrossRef] 
34. Solaimanian, M.; Savory, E. Variability Analysis of Hot-Mix Asphalt Concrete Containing High Percentage of Reclaimed Asphalt Pavement. Transp. Res. Rec. J. Transp. Res. Board 1996, 1543, 13-20. [CrossRef]

35. Romier, A.; Audeon, M.; David, J.; Martineau, Y.; Olard, F. Low-Energy Asphalt with Performance of Hot-Mix Asphalt. Transp. Res. Rec. 2006, 1962, 101-112. [CrossRef]

36. Motta, R.S. Estudo de Misturas Asfálticas Mornas em Revestimentos de Pavimentos para Redução de Emissão de Poluentes e de Consumo Energético; Escola Politécnica da Universidade de São Paulo: São Paulo, Brazil, 2011.

37. Lecomte, M.; Deygout, F.; Menetti, A. Emission and Occupational Exposure at Lower Asphalt Production and Laying Temperatures; Shell Bitumen: London, UK, 2007.

38. Hurley, G.C.; Prowell, B.D.; Kvasnak, A.N. Ohio Field Trial of Warm Mix Asphalt Technologies: Construction Summary; National Center for Asphalt Technology: Auburn, AL, USA, 2009.

39. Anderson, R.; Baumgardner, G.; May, R.; Reinke, G. Engineering properties, emissions, and field performance of warm mix asphalt technologies. In Transportation Research Board of the National Academies Privileged Document; National Cooperative Highway Research Program: Washington, DC, USA, 2008.

40. Sharma, A.; Lee, B.K. Energy savings and reduction of $\mathrm{CO}$ emission using $\mathrm{Ca}(\mathrm{OH}) 2$ incorporated zeolite as an additive for warm and hot mix asphalt production. Energy 2017, 136, 142-150. [CrossRef]

41. Giani, M.I.; Dotelli, G.; Brandini, N.; Zampori, L. Comparative life cycle assessment of asphalt pavements using reclaimed asphalt, warm mix technology and cold in-place recycling. Resour. Conserv. Recycl. 2015, 104, 224-238. [CrossRef]

42. Peinado, D.; de Vega, M.; García-Hernando, N.; Marugán-Cruz, C. Energy and exergy analysis in an asphalt plant's rotary dryer. Appl. Therm. Eng. 2011, 31, 1039-1049. [CrossRef]

43. Kristjánsdóttir, Ó.; Muench, S.; Michael, L.; Burke, G. Assessing Potential for Warm-Mix Asphalt Technology Adoption. Transp. Res. Rec. J. Transp. Res. Board 2007, 2040, 91-99. [CrossRef]

44. Harder, G.A.; LeGoff, Y.; Loustau, A.; Martineau, Y.; Heritier, B.; Romier, A. Energy and environmental gains of warm and half-warm asphalt mix: Quantitative approach. In Proceedings of Transportation Research Board 87th Annual Meeting, Washington, DC, USA, 13-17 January 2008.

45. EAPA. The Use of Warm Mix Asphalt. EAPA-Position Pap; EAPA: Belgium, Brussels, 2010; pp. 1-13.

46. Almeida-Costa, A.; Benta, A. Economic and environmental impact study of warm mix asphalt compared to hot mix asphalt. J. Clean. Prod. 2016, 112, 2308-2317. [CrossRef]

(C) 2020 by the authors. Licensee MDPI, Basel, Switzerland. This article is an open access article distributed under the terms and conditions of the Creative Commons Attribution (CC BY) license (http://creativecommons.org/licenses/by/4.0/). 